\title{
Incorporating the Principles of Critical Pedagogy into a Teacher Efficacy Measure
}

\author{
Mahsa Izadinia \\ School of Education, Psychology and Pedagogy, Victoria University of Wellington \\ PO Box 17-310, Karori, Wellington 6147, New Zealand \\ Tel: 64-226-892-991_E-mail: Mizadiniya2006@yahoo.com
}

Received: January 8, 2011 Accepted: January 18, 2011 doi:10.5539/elt.v4n2p138

\begin{abstract}
Although critical pedagogy has defined new roles for teachers through which they can step beyond classroom concerns, there seems to be little attention to these roles in the conceptualization and measures of teacher efficacy. This study was an attempt to review the available literature and measures of teacher efficacy to find out whether the principles of critical pedagogy have been incorporated into operational and theoretical aspects of teacher efficacy. The absence of these principles called for including such items in one of the most recent and valid teacher efficacy measures and construct validating the new scale.
\end{abstract}

Keywords: Critical pedagogy, Teacher efficacy measures, TSES, TSES-CP.

\section{Introduction}

Education, baby-like, has passed from infancy to adolescence. Considerable changes have occurred over the past decades in many aspects of education which have altered the purpose of education and its definition. For instance, with the arrival of critical pedagogy (CP) (Freire, 1972; Giroux, 1988; McLaren, 1995) in education, teachers and students have found new identities and roles. In light of the premises of critical pedagogy, teachers who were deemed as unquestioned authorities have come down from their sacred and safe places to a more friendly and open environment wherein they can negotiate the class procedures, structure, content, grading criteria as well as their own roles in relation to students. At the same time, the view towards students has changed. Good students in CP are characterized not as those who would meekly permit themselves to be filled with knowledge (Freire, 1972), but as critical autonomous who can analyze, criticize, and question not only the materials they are studying but also the context they are living in so that they can better themselves, strengthen democracy, create a more just society, and, thus, deploy education in a process of progressive social change (Kellner, 2000).

This ground shifting has not ended in classrooms but it has found its way into a wider and more real context (i.e., the society). The ideas of sharing authority, negotiation, and humanization to which the changes in classrooms owe a lot, have brought a new life to students as social participants as well. Students have been invited to be active and critical members in their society and to critique and challenge oppressive social conditions (Freire, 1972). By the same token, teachers have been encouraged to be 'Transformative intellectuals' (Giroux, 1988) and resist the assumption that they are simply transmitters of knowledge. In other words, they have been invited to be sociopolitically conscious and strive not only for educational advancement but also for personal and social transformation (Kumaravadivelu, 2003). It is worth nothing that not all students and teachers have been lucky enough to enjoy these positive changes. There are still many classrooms where students receive the same traditional schooling and many teachers who still believe their sole responsibility is to impart knowledge. Yet, as stated above, changes toward transformative education have occurred in some societies.

Along with and due to the new identities teachers have been given in transformative education, novel and broader definitions of an effective teacher and his/her qualities have been offered. More specifically, since the effectiveness of any education program is attributable, to a great extent, to the effectiveness of teachers in discharging responsibilities defined for them in different capacities, researchers throughout the history of education, especially in the last few decades, have sought those teacher characteristics which guarantee positive teaching behavior and student outcomes (Henson, 2001; Tschannen-Moran, Woolfolk Hoy, \& Hoy, 1998). Teacher effectiveness, for instance, has been repeatedly associated with verbal skills, content knowledge, pedagogical techniques, cultural sensitivity, technological proficiency and interpersonal skills (Settlage, Southerland, Moore, \& Schademan, 2003). In this long list, teacher sense of efficacy with a history of more than two decades, has received more attention (Tschannen-Moran et al., 1998). 
Teacher efficacy, which is defined as "the extent to which the teacher believes he or she has the capacity to affect student performance" (Berman, McLaughlin, Bass, Pauly, \& Zellman, 1977, p.137), is considered a "future-oriented motivational construct that reflects teachers' competence beliefs for teaching tasks" (Fives, 2003 p. 3). The concept of teacher efficacy is theoretically rooted in Rotter's locus of control (1966) and Bandura's social cognitive theory (1977). Each of these theories has provided a basis for the work of researchers in defining and measuring the teacher efficacy construct. In locus of control, teacher efficacy is conceptualized as the degree to which an individual believes that the perceived cause(s) of an intended outcome are within his or her control (Rotter, 1966). Following this stand, Rand researchers (Armor et al., 1976) developed a two-item scale for measuring teacher efficacy and defined it as the extent to which teachers believe they can control the reinforcement of their actions. Other measures developed based on Rotter's conceptualization are: Teacher's Locus of Control (Rose \& Medway, 1981) Responsibility for Student Achievement (Guskey, 1981), and the Webb Scale (Ashton, Olejnik, Crocker, \& McAuliffe, 1982).

The second group of measures is rooted in Bandura's social cognitive theory (1977). In his theory, Bandura introduces the concept of self-efficacy as the primary motivational force behind an individual's actions and defines it as "the conviction that one can successfully execute the behavior required to produce outcomes" (p. 193). Among the measures developed based on Bandura's theory, are the Ashton's Events Scale (Ashton, Olejnik, Crocker, \& McAuliffe, 1982), the Teacher Efficacy Scale (Gibson \& Dembo, 1984), and the Efficacy Beliefs in Science Teaching Scale (Riggs \& Enochs, 1990), to name a few.

The developed teacher efficacy scales have been used by a host of researchers interested in finding the relationships between teacher efficacy and other variables, including student achievement (McLaughlin \& Marsh, 1978), teacher's extra-role behavior (Somech \& Drach-Zahavy, 2000), teachers' ability in shaping students' attitudes toward school, subject matter, and even the teacher (Woolfolk, Rosoff, \& Hoy, 1990), and teacher's classroom management (Emmer, 1990; Emmer \& Hickman, 1990).

The advocates of $\mathrm{CP}$ have not remained silent over the past years as mentioned above and have contributed to the issues concerning teachers' effectiveness by referring to their roles in creating active and critical students (Freire, 1972; Kumaravadivelu, 2003, 2006). Yet, it seems that the scales developed for measuring the construct of teacher efficacy mainly include items related to classroom-bound concerns such as efficacy for managing the class, giving effective instructional strategies, and engaging students. In other words, the set of values held in $\mathrm{CP}$ as its main premises seem to have been overlooked in the studies done on and the scales developed for measuring teacher efficacy (Labone, 2004).

The importance of having the principles of CP in teacher efficacy measures lies in the fact that teachers grow more conscious of the sociopolitical roles they have. When most of teacher efficacy measures are revolving around classroom-bound concerns and fail to capture the richness and complexity of classroom life, teachers might not even picture themselves doing anything beyond such responsibilities. In other words, the absence of the principles of $\mathrm{CP}$ in these measures diverts the teachers' attention from the sociopolitical roles they possess to more classroom-bound issues. Therefore, this work is intended to address this gap by incorporating some of the premises of $\mathrm{CP}$ into a teacher efficacy measure. The research questions posed in this study are:

\section{Research questions}

1. To what extent does research on teacher efficacy address principles of critical pedagogy?

2. To what extent do teacher efficacy measures factor in principles of critical pedagogy?

3. How can principles of $\mathrm{CP}$ be incorporated into a teacher efficacy measure?

\section{Method}

The first phase of this study was a review done on the studies of teacher efficacy and the measures developed for it to explore the extent to which they had taken into account the premises of $\mathrm{CP}$ and/or its subcategories. To this end, first, all the available studies of teacher efficacy, including 54 articles along with some books and chapters were reviewed based on a checklist consisting of principles of CP which were compiled by Crawford (1978) and Giroux (1992). At the next stage, all the available English measures of teacher efficacy were reviewed against this checklist in order to explore the degree to which their designers had factored the principles of CP into these measures. The measures reviewed for this study were: The Rand Scale (Armor et al., 1976); Ashton's Events Scale (Ashton, Buhr, \& Crocker, 1984); the Webb Scale (Ashton et al., 1982); Teacher Interpersonal Self-Efficacy Scale (Brouwers \& Tomic, 2001); Teacher's Efficacy Belief System-self (Dellinger, Bobbett, Olivier, \& Ellett, 2008); Bandura's Teacher Efficacy Scale (Friedman \& Kass, 2001); Teacher Efficacy Scale (Gibson \& Dembo, 1984); Responsibility for Student Achievement (Guskey, 1981); the Efficacy Beliefs in Science Teaching Scale (Riggs \& Enochs, 1990); Teacher's Locus of Control (Rose \& Medway, 1981); Teachers' Sense of Efficacy Scale (Tschannen-Moran \& 
Woolfolk Hoy, 2001); Culturally Responsive Teaching Self-Efficacy and Culturally Responsive Teaching Outcome Expectancy (Siwatu, 2007).

Based on the review done on teacher efficacy literature and its measures, it became clear that the principles of $\mathrm{CP}$ were not paid due attention in the studies and the measures of teacher efficacy as initially assumed. Therefore, in the next phase of the study, some of the principles of $\mathrm{CP}$ were factored into a teacher efficacy measure. More precisely, first, the already produced checklist was shortened to a list comprising of nine based on the commonality of the items. The selected items were added to an already existing teacher efficacy scale called TSES (Teachers' Sense of Efficacy Scale by Tschannen-Moran \& Woolfolk Hoy, 2001). The reason why I opted for this scale was the advantages of this scale including its multidimensionality and specificity of teacher efficacy (Fives, 2003) and having a unified and stable factor structure which are more interpretable and more specific to teaching tasks (Woolfolk Hoy \& Spero, 2005). The long form of this measure which was used in this study has twenty four items and a 9-point scale with anchors at 1- nothing, 3 - very little, 5 - to some degree, 7 - quite a bit, and 9 - a great deal. The factor structure of TSES includes efficacy for instructional strategies, efficacy for classroom management, and efficacy for student engagement.

As mentioned above, the selected CP items were added to TSES and the attempts were made to change the format of these items so that they fit the format adhered to in TSES. In other words, since teacher efficacy measures, in general, and TSES, in particular, intend to measure teachers' perceived efficacy in doing different teaching tasks, the questions usually start with phrases such as "How much can you,". Therefore, the developed items were also changed according to this format. Finally, the developed questionnaire was administered to 48 English language teachers teaching mainly in English institutes, universities and high schools in Tehran and some other cities in Iran for the pilot study and 241 other English language teachers in the validation part. The teaching experience of these groups of participants ranged from one to eighteen years.

Below the findings of the review done on studies and measures of teacher efficacy are reported.

\section{Findings}

\subsection{CP in Research on Teacher Efficacy}

Based on the results of the review done on the studies of teacher efficacy, it was found that only three studies had given weight to the concept of CP or, more specifically, to its subcategories, and interestingly, in two of them, they had referred to the absence of such concepts in teacher efficacy measures in one way or another. These studies are briefly discussed below.

3.1.1The case for reconceptualizing teacher efficacy research (Wheatley, 2005)

Wheatley (2005) has done a detailed analysis by reviewing more than 180 articles related to teacher efficacy, in particular, and self-efficacy beliefs in general, in addition to reviewing teacher efficacy scales. Referring to the narrow applicability of teacher efficacy scales for teacher educators, Wheatley argues that teacher efficacy scales do not reflect democratic teaching which shares some common ground with CP such as equality, freedom, and justice. He provides three reasons for his argument and, finally, calls for a new definition of teacher efficacy beliefs, broader in meaning and measure. Two of his reasons are discussed below.

\subsubsection{Individualistic efficacy, collaborative teaching}

Wheatley argues that the "I can" language of many of the items of teacher efficacy scales concentrates all positive outcomes in the hands of the teacher and ignores the constructive role of students, other teachers and the collaboration between the concerned parties. In other words, individual teacher's exercise of agency (I can do it) has received more emphasis than collaborative agency.

\subsubsection{Conflicting visions of teacher control}

Wheatley also refers to the direct personal control of teacher implicit in teacher efficacy scales. He believes that in many of the items of the teacher efficacy scales, such as "I can get through to students", teachers are asked about their perceived ability to do what it takes to directly cause specified student outcomes (Guskey \& Passaro,1994; Soodak \& Podell, 1996). Although direct control has always had a place in teaching, he asserts that democratic teaching has shifted the emphasis from teacher control to more shared control (Bredekamp \& Copple, 1997) such as students taking responsibility for their own learning and other students' outcomes. Wheatley concludes that traditional views of teacher control obstruct the teacher's use of democratic methods and as mentioned above, he expresses the need for broadening the construct of teacher efficacy to include more democratic teaching.

3.1.2 Teacher efficacy: maturing the construct through research in alternative paradigms (Labone, 2004)

Labone (2004) also refers to the underlying assumptions of critical theories and the emphasis they put on the vital role of schools within society in fostering issues of social justice and power. She foregrounds the necessity of 
extending teachers' role beyond classroom concerns and developing skills that enable students to change the life chances they possess. Labone (2004) argues that teacher efficacy research should consider types of efficacy that facilitate social reconstruction, whereas, as evidenced by the review she had done on teacher efficacy measures, they have focused more on instructional issues, for instance, within the classroom.

3.1.3 Preservice teachers' culturally responsive teaching self-efficacy and outcome expectancy beliefs (Siwatu, 2007)

Siwatu (2007) refers to a need for the implementation of equitable and culturally sensitive instructional practices by preservice teachers. This approach to teaching which has been called culturally responsive teaching (Gay, 2000), culturally congruent instruction (Mohatt \& Erickson, 1981), is an approach to teaching and learning that "(1) uses students' cultural knowledge (2) incorporates students' cultural orientations to design culturally compatible classroom environments" (Siwatu, 2007, pp.1087-1089). Siwatu believes that the preservice teaching training programs are the right place for incorporating culturally responsive teaching practices which can be a "positive step towards aligning the teacher education curriculum (coursework, field experiences), learning and performance objectives, and assessment of competence" (Siwatu, 2007 p. 1087). Developing CRTSE (Culturally Responsive Teaching Self-Efficacy scale) and CRTOE (Culturally Responsive Teaching Outcome Expectancy), Siwatu (2007) tries to measure the efficacy of preservice teachers for executing the practices of culturally responsive teaching. It is worth mentioning that issues related to culture are among the premises of critical pedagogy.

The three articles discussed above were the only ones which, to some extent, referred to the absence of CP and/or its related issues among teacher efficacy measures and studies in one way or the other.

\subsection{CP in Measures of Teacher Efficacy}

At the next stage, all the available measures of teacher efficacy were reviewed. As evidenced by the results of Labone's work (2004), the conceptual structures of almost all the reviewed measures of teacher efficacy showed that the construct of teacher efficacy is generally concerned with "lesson delivery" and, consequently, it lacks the principles of CP. However, out of thirteen measures eight included one or two items concentrating on the premises of $\mathrm{CP}$ in addition to items related to instructional strategies and classroom management. For instance, in Teacher Locus of Control (Rose \& Medway, 1981) one of the items is related to the role of teacher in the social development of children. This item can be counted among the premises of critical pedagogy. Also in the Webb Scale (Ashton et al., 1982) there is an item related to the relationship between teaching and students' lives which can considered as one of the principles of critical pedagogy. Other measures in this category were: Ashton Vignettes (Ashton et al., 1984), Bandura's Teacher Efficacy Scale (Friedman \& Kass, 2001), Teachers' Sense of Efficacy Scale (Tschannen-Moran \& Woolfolk Hoy, 2001), the Teacher's Efficacy Belief System-self (Dellinger et al., 2008) and Teaching Self-Efficacy and Culturally Responsive Teaching Outcome Expectancy (Siwatu, 2007). As sated above, in these masseurs only one or two items out of a total of twenty five, for instance, were related to the principles of critical pedagogy.

\subsection{Construct Validation of TSES-CP}

\subsubsection{Item analysis}

Based on the findings gathered from the review done on studies and measures of teacher efficacy, it was concluded that $\mathrm{CP}$ has not received enough attention by researchers and its premises have not been adequately incorporated in the measures of teacher efficacy. Therefore, as stated above, nine items which seemed to best reflect the principles of CP were factored into TSES. The resultant questionnaire, called TSES-CP, was administered to 48 English language teachers in the pilot study. To analyze the data, Extreme Group Method and Corrected Item-Total Correlation were conducted. In Extreme Group Method an item is considered acceptable if it discriminates well between the total test scores of the upper 33 percent and the lower 33 percent of the participants. To this end, an independent sample t-test was run. The results of t-test indicated that four items $(1,25,28, \& 30)$ did not discriminate well between the upper and lower groups. In other words, t-test for independent samples carried out on the data was not significant at.05 level (two-tailed, equal variances assumed).

With regard to Corrected Item-Total Correlation, an item is considered suspect if its correlation with the total scale is below .05 (Tseng, Dornyei, \& Schmitt, 2006), which shows that the relationship between that item and the total score is weak. The analysis of data showed that the correlations were not significant at.05 for items 28 and 30 . The reliability of the data was also determined through using Cronbach Alpha and the result showed a high reliability (917).

Based on the above results, items 1, 25, 28, and 30 were considered vague and their wordings were changed. At the next stage, the questionnaire was administered again for the validation phase to 241 other English language teachers. After the second administration of the questionnaire, the data was item analyzed again to see if the changes made in the problematic items have enhanced the previous results and the results showed that the t-test for items $1,25,28$, 
and 30 was significant at the .05 level (two-tailed, equal variances assumed). Also, the results of Item-Total Correlation showed the correlation coefficients between items 28 and 30 and the total scale were significant at .05 (See Appendix A for TSES-CP).

\subsubsection{Factor analysis}

In order to construct validate TSES-CP, after the second administration, factor analysis was run. For this part, principle axis factoring was used and for the rotation procedure, orthogonal rotation and among orthogonal rotation Varimax rotation was implemented. The reason why orthogonal rotation was used was due to the fact that the variables in this study were assumed to be not correlated. Moreover, the extracted factors in TSES were also assumed to be uncorrelated (Tschannen-Moran \& Woolfolk Hoy, 2001). Among orthogonal rotations, Varimax which is the most commonly used and efficient procedure was chosen. To find the right number of factors to extract, the Kaiser criterion and the Scree test were employed and a a 3 factor solution was run. The result of the analysis showed that the items loading on one factor were considerably unrelated and the result was to a large extent uninterpretable. Moreover, the loading of one of the items, (item 10) was much lower than .3 (.12). Therefore, a 4 factor solution was run next. This time the loadings increased and the factor structure appeared to be more interpretable. However, item 10 remained problematic. Although the loading of item 10 reached .86, it stood alone under factor 4 . Since the number of items under each factor should be more than 3 and a 1 item factor does not make sense, the researcher decided to delete this item. After item 10 was deleted, the 4 factor solution was run again. Here the interpretability of the factor structure improved significantly and the loadings also increased. Table 1 shows the total variances of each item

Insert Table 1 here

As shown in the Percentage of Variance column, four factors have been extracted in the factor analysis (Factor 1: Efficacy for Instructional Strategies, Factor 2: Efficacy for Classroom management, Factor 3: Efficacy for Student Engagement, and Factor 4: Efficacy for Playing Critical and Social Roles). The first, second, third, and fourth Factors account for $11.43 \%, 10.43 \%, 10.24 \%$, and $7.50 \%$ of the total variance respectively. The four Factors altogether account for $39.61 \%$ of the total variance, and this seems to be somehow lower than desirable. The eigenvalues of Factors 1 to 4 are 3.65, 3.33, 3.27, and 2.40 respectively.

Table 2 shows the descriptive statistics of TSES-CP (i.e., the minimum, maximum, mean and standard deviation of each item). As depicted in Table 2, the highest mean belongs to item 25 which means the participants in this study have had the highest perceived efficacy in fulfilling the task related to having friendly relationship with students. The lowest mean however, belongs to item 8 which means the participants' lowest perceived self efficacy has been related to changing students into socio-politically responsible participants in society. The highest and lowest standard deviations belong to item 8 and 25 respectively.

Insert Table 2 here

Table 3 shows the factor structure of TSES-CP. It is worth mentioning that the order of extracted factors in the present study is slightly different from that of Tschannen-Moran and Woolfolk Hoy (2001). More precisely, while in their study factors 1, 2 and 3 were Efficacy for Instructional Strategies, Efficacy for Classroom Management, and Efficacy for Student Engagement, respectively, in this study the four extracted factors are Efficacy for Playing Critical and Social Roles, Efficacy for Instructional Strategies, Efficacy for Classroom Management, and Efficacy for Student Engagement.

Insert Table 3 here

The reliability of the whole questionnaire and each factor was estimated as well through Cronbach Alpha. Table 4 shows the reliability of TSES-CP.

Insert Table 4 here

\section{Discussion}

In this section, the movements of the items across the factors as compared to their original standing in TSES as well as the grouping of the new set of items (i.e., those reflecting principles of critical pedagogy) are discussed.

The first factor which is the newly extracted factor accounts for more variance than the rest of the factors and is called "Efficacy for Playing Critical and Social Roles". This factor includes both the new items related to CP plus two items ( 2 and 22) from Factor 4 (Efficacy for Student Engagement). Item 2 (How much can you do to help your students think critically?) which was the only original item focusing on CP principles has fallen into this category. This factor is the best place for this item since it is related to fostering critical thinking ability in students which is among the key issues discussed and highlighted in $\mathrm{CP}$ and thus goes well with this factor. 
Item 22 (How much can you assist families in helping their children do well in class work?) is concerned with parental involvement which, as explained before, has its roots in CP and transformative education and has received constant attention by the followers of CP(Mayo, 2003). The rest of the items are all the newly developed ones, and they deal with teachers' perceived efficacy for performing social roles and for weaving together the classroom life and social life of students.

As Table 3 shows, the second extracted factor is "Efficacy for Instructional Strategies." The first item, (To what extent can you help students produce their own learning materials?), as explained in the parentheses, is related to the new set of items concerning critical pedagogy. Although the item was expected to load on the factor related to Efficacy for Playing Critical and Social Roles (Factor 1), it has been grouped under Efficacy for Instructional Strategies. Yet this grouping seems logical, that is, the relevance and appropriateness of the materials produced by students heavily depend on the effectiveness of the instructions given by teachers. In other words, students need clear instructions to be able to produce their learning materials and grouping of this item among items related to teachers' perceived efficacy in instructional strategies seems logical. Moreover, the abovementioned item has added a critical flavor to the Efficacy for Instructional Strategies since it throws light on teachers' efficacy for using appropriate strategies which can make students responsible for their own learning contents. Implementation of these strategies will result in having a curriculum which derives from the life situations of students, and this is in line with the premises of CP (Crawford, 1978). However, items 18, 23,7,17, and 11 have fallen into the same factor as they did in the factor analysis run by Tschannen-Moran and Woolfolk Hoy (2001).

Item 16 (How well can you establish a classroom management system with each group of students?) which previously belonged to "Efficacy for Classroom Management" (Factor 3) in TSES factor structure has also moved to this group (Efficacy for Instructional Strategies). Although any movement of the items across the four factors is completely expected, as mentioned above, this item seems to be more interpretable in its previous place since it directly questions the efficacy for managing the class. The present statistical analysis is also partly in line with this logic. More precisely, based on Table 2 which shows all loadings above .3 on the four factors, the loading of this item on Factor 3 (Efficacy for Classroom Management) is .463 as compared to its loading on Efficacy for Instructional Strategies (.487). The difference between the two loadings is only about .02. This very low statistical difference can be ignored and the item can be considered to belong to the factor on which it has the lower loading $(\mathrm{H}$. Farhady, personal correspondence, March 29, 2006). This reasoning led us to group this item under Factor 3 so that the categorization will be more interpretable.

Items 13, 9, and 14 which had loaded on Efficacy for Student Engagement (Factor 2) in the TSES factor structure have come to this factor as well. As the items show, they really fit into this category since they all call for efficacious use of instructional strategies on the part of teachers. More precisely, a teacher may use instructional strategies to, for instance, help the students value learning (item 9), encourage their creativity (item 13) and improve the understanding of students who are failing (item 14).

Moreover, as Table 3 shows, the loadings of items 13 and item 14 on Factor 2 are only around .03 and .01, respectively, higher than the loadings of these items on Factor 1 (Efficacy for Playing Critical and Social Roles). Classifying these items into Factor 1 seems appropriate as well, especially with regard to item 13, since encouraging creative actions on the part of students is also among the principles of $\mathrm{CP}($ Crawford, 1978). This explanation is not meant to imply that one can always apply logic in categorization and movement of items whenever the differences in the loadings seem insignificant. However, we intend to shed light on how such slight differences indicate the likelihood of variations in the factor structure of this questionnaire in other studies.

The next extracted factor (Factor 3) is "Efficacy for Classroom Management." As shown in Table 2 almost all of the items having loaded on this factor in TSES have come into the same category in the new factor analysis, and there is only one item (How much can you have a friendly relationship with students?) which is a newly developed question related to critical pedagogy. Apparently, the factor analysis which has grouped the item under the classroom management questions the initial logic for grouping this item in "Efficacy for Playing Critical and Social Roles". However, the new grouping seems, at least, equally logical since developing close rapport with learners can most probably make great contributions to effective classroom management.

The last factor (Efficacy for Student Engagement) has two items related to CP (27 \& 29). Item 27 (How much can you learn from your own classes?) may seem uninterpretable in this category; however, if one agrees with the idea of teachers as constant learners (Crawford, 1978), s/he can conceive of the teacher as one of the learners who should make use of every single moment of teaching-learning process to learn something new from the situations which arise in the classroom. Another justification for this observation is that teachers' engagement in the learning process motivates learners to become more engaged in the learning process as well, since the teacher is considered as a model by learners (Timmerman, 2009). 
Item 29 (To what degree can you invite students to contribute to the decisions made in the classroom?) which is the other item having loaded on Factor 4, completely fits into its new category and, specifically, inserts a critical dimension into this aspect of teacher efficacy. More precisely, letting students speak their minds and make their voice heard in the classroom may set the ground for them to become deeply and actively involved in all aspects of the learning-teaching process (Alford, 2001; Freire \& Macedo, 2003; Ranson, 2000). With regard to its critical contributions to this factor, it can be mentioned that providing students with leeway to take part in the decision making process makes them active members when they enter the society.

Items 6 and 4 had loaded on Efficacy for Student Engagement in TSES factor structure and remained there in the new factor analysis. Item 21 (How well can you respond to defiant students?) has moved from Efficacy for Classroom Management (Factor 3) to Efficacy for Student Engagement. Their being in this new category makes sense, since responding to a defiant student may lead to that student's increased engagement in classroom activities. That is, when a defiant student is treated appropriately, it not only makes that student participate in class activities more actively but also prevents other students from being distracted by the aggressive and unruly behavior of that student. Therefore, appropriate treatment of defiant students on the part of teachers results in students' engagement in class activities.

Items 24 and 20, which had been under Factor 2 (Efficacy for Instructional Strategies) in TSES factor structure, have moved to this factor as well. Similar to most of the above transferences, it seems logical to justify this transmission of items from "Efficacy for Instructional Strategies" to "Student Engagement" by concluding that through "providing appropriate challenges for very capable students" (item 24), a teacher can match the difficulty level of the lessons and tasks to students' ability and, thus, increase their interest and engagement in class activities.

The same justification holds true for item 20 (To what extent can you provide alternative explanation or example when students are confused?). In other words, by giving alternative explanations and examples, a teacher can engage students in classroom routines in order to prevent their losing track of classroom activities.

\section{Conclusion}

This study was an attempt to foreground a neglected aspect of teacher efficacy measures. It was argued that, in the teacher efficacy measures developed so far, teachers' effectiveness is usually assessed against their ability to fulfill a range of classroom-bound and technically-oriented tasks such as using certain instructional strategies and managing the class. What have been practically ignored in these measures are sociopolitical roles of teachers such as engaging students in critical dialogue, classroom decisions, power sharing, and critical thinking which enable them to act as agents of change in their social lives.

To address the first research question raised in this study, I reviewed all the available studies on teacher efficacy to explore the extent to which they had taken into account the premises of CP or the sociopolitical roles of teachers. Only three studies were found to have focused on critical issues related to teacher efficacy, two of which had called for more attention to these issues in teacher efficacy research. To answer the second research question, all the available English measures of teacher efficacy were reviewed against a checklist consisting of the main principles of critical pedagogy. The result of this review showed that only eight measures out of 30 had included one or two items related to critical pedagogy. This observation encouraged me to factor some of the main tenets of CP into an existing teacher efficacy measure and construct validate the extended scale.

\section{Implications}

Given the fact that teacher efficacy measures are used by researchers and policy makers to assess the effectiveness of teachers, the fairness and adequacy of these measures should be of utmost importance to their developers. One of the ways through which this fairness could be achieved is by taking into account the sociopolitical roles of teachers in addition to their classroom-bound responsibilities in measures of teacher efficacy. In other words, defining teachers' roles only in terms of their effectiveness in imparting knowledge and imposing discipline and not recognizing their enormous potential for acting as change agents does not do justice to their multifaceted roles. This, in turn, might result in diverting teachers' attention away from their transformative roles (Freire, 1972) and reducing them to passive technicians (Kumaravadivelu, 2003) whose sole responsibility is to practice others' theories and transfer given information to students.

Construct validating a teacher efficacy scale equipped with the principles of $\mathrm{CP}$, the present study had made it possible to measure the construct of teacher efficacy in terms of teachers' perceived efficacy in serving dual roles (i.e., transmitting knowledge and transforming individuals and society).

\section{Limitations of the Study}

One key limitations of this study is that the participants are confined to English language teachers and not teachers from all subject matters. It could be beneficial to extend the scope of this study by including teachers from all 
subject matters. Another limitation is the number of participants which is only 241 . The more interpretable and consistent the extracted factor structure will be if we have more participants.

\section{Suggestions for Further Research}

There is work to be done to further test and validate TSES-CP. As explained before, the four extracted factors altogether account for merely $39.61 \%$ of the total variance and this means around $60 \%$ of the total variance is not accounted for by the present factor structure. Therefore, further studies might look into the consistency of the factor structure and investigate whether the present developed scale can have a more interpretable underlying factorial structure.

\section{References}

Alford, J. (2001). Critical literacy and second language learning in the mainstream classroom: an elusive nexus? In P. Singh and E. McWilliam (Ed.), Designing educational researches: theories, methods and practices (pp. 127-139). Flaxton, Australia: Post Pressed

Armor, D., Conroy-Oseguera, P., Cox M., King, N., McDonnell, L., Pascal, A. Pauly, E., \& Zellman, G. (1976). Analysis of the school preferred reading programs in selected Los Angeles minority schools. (Report No. R-2007-LAUSD). Santa Monica, CA: Rand Corporation. (ERIC Document Reproduction Service No. 130243).

Ashton, P., Buhr, D., \& Crocker, L. (1984). Teachers' sense of efficacy: A self- or norm-referenced construct? Florida Journal of Educational Research, 26, 29-41.

Ashton, P. T., Olejnik, S., Crocker, L., \& McAuliffe, M. (1982). Measurement problems in the study of teachers' sense of efficacy. Paper presented at the annual meeting of the American Educational Research Association, New York.

Bandura, A. (1977). Self-efficacy: Toward a unifying theory of behavioral change Psychological Review, 84, 191-215.

Berman, P., McLaughlin, M., Bass, G., Pauly, E., Zellman, G. (1977). Federal Programs supporting educational change. Vol. VII Factors affecting implementation and continuation (Report No. R-1589/7-HEW) Santa Monica, CA: The Rand Corporation (ERIC Document Reproduction Service No. 140 432).

Bredekamp, S., \& Copple, C. (1997). Developmentally appropriate practice in early childhood programs (Rev. ed.). Washington, DC: National Association for the Education of Young Children.

Brouwers, A. \& Tomic, W. (2001). The factorial validity of scores on the teacher interpersonal self-efficacy scale. Educational and Psychological Measurement, 61 (3), 433-445.

Crawford, L.M. (1978). Paulo Freire's philosophy: Derivation of curricular principles and their application to second design. Unpublished doctorial dissertation, University of Minnesota.

Dellinger, A.B., Bobbett, J.J., Olivier, D.F., \& Ellet, C, D. (2008). Measuring teachers' self-efficacy beliefs: Development and use of the TEBS-Self. Teaching and Teacher Education, 24, 751-766.

Emmer, E. (1990). A scale for measuring teacher efficacy in classroom management and discipline. Paper presented at the annual meeting of the American Educational Research Association, Boston.

Emmer, E., \& Hickman, J. (1990, April). Teacher decision making as a function of efficacy, attribution, and reasoned action. Paper presented at the annual meeting of the American Educational Research Association, Boston, MA.

Fives, H. (2003). What is teacher efficacy and how does it relate to teachers' knowledge? a theoretical review. Paper presented at the American Educational Research Association Annual Conference, University of Maryland.

Freire, P. \& Macedo, D. (2003). Rethinking literacy: a dialog. In A. Darder, M. Baltodano, and R.D. Torres, (Ed.), CPreader (pp. 354-364). New York: Routledge, Falmer.

Freire, P. (1972). Pedagogy of the oppressed. New York: Penguin Books.

Friedman, I. A. \& Kass, E. (2001).Teacher self-efficacy: A classroom-organization conceptualization. Teaching and Teacher Education 18, 675-686.

Gay, G. (2000). Culturally responsive teaching: Theory, research, and practice. New York: Teachers College Press.

Giroux, H. (1992). Border crossings: Cultural workers and the politics of education. New York: Routlege.

Giroux, H. A. (1988). Teachers as intellectuals: Towards a CPof learning. South Hadley, Massachusetts: Bergin \& Garvey. 
Gibson, S., \& Dembo, M. (1984). Teacher efficacy: A construct validation. Journal of Educational Psychology, 76, 569-582.

Guskey, T. R. (1981). Measurement of responsibility teachers assume for academic successes and failures in the classroom. Journal of Teacher Education, 32, 44-51.

Guskey, T. R., \& Passaro, P. D. (1994). Teacher efficacy: A study of construct dimensions. American Educational Research Journal, 31, 627-643.

Henson, R. K. (2001). Teacher Self-efficacy: Substantive Implications and Measurement Dilemmas. Paper presented at the annual meeting of the Educational Research Exchange, Texas.

Kumaravadivelu, B. (2003). Beyond methods: Macrostrategies for language teaching. Yale University Press: New Haven and London.

Kumaravadivelu, B. (2006). Understanding language teaching: From method to post method. Mahwah, New Jersey: Lawrence Erlbaum Associates.

Labone, E. (2004). Teacher efficacy: Maturing the construct through research in alternative paradigms. Teaching and Teacher Education 20, 341-359.

Mayo, P. (2003). A rational for a transformative approach to education. Journal of Transformative Education, $1,38-57$.

McLaren, P. (1995). CPand predatory culture. London: Routledge.

McLaughlin, M.W., \& Marsh, D.D. (1978). Staff development and school change. Teachers College Record, 80, 70-94.

Mohatt, G., \& Erickson, F. (1981). Cultural differences in teaching styles in an Odawa school: A sociolinguistic approach. In H. Trueba, G. Guthrie, \& K. Au (Eds.), Culture and the bilingual classroom: Classroom ethnography (pp. 105-119). Rowley, MA: Newbury House.

Ranson, S. (2000). Recognizing the pedagogy of voice in a learning community. Educational management and administration, 28(3): 263-379.

Riggs, I., \& Enochs, L. (1990). Toward the development of an elementary teacher's science teaching efficacy belief instrument. Science Education, 74, 625-638.

Rose, J. S., \& Medway, F. J. (1981). Measurement of teachers' beliefs in their control over student outcome. Journal of Educational Research, 74, 185-190.

Rotter, J. B. (1966). Generalized expectancies for internal versus external control of reinforcement. Psychological Monographs, 80, 1-28.

Settlage, J., Southerland, S., Moore, F., \& Schademan, A. (2003). The Rise and fall of teacher efficacy: The prospects of teaching actual and not illusory students. Paper presented in the annual meeting of the Association of the Education of Teachers in Science.

Siwatu, K. O. (2007). Preservice teachers' culturally responsive teaching self-efficacy and outcome expectancy beliefs. Teaching and Teacher Education 23 (7), 1086-1101.

Somech, A., \& Drach-Zahavy, A. (2000). Understanding extra-role behavior in schools: the relationships between job satisfaction, sense of efficacy, and teachers' extra-role behavior. Teaching and Teacher Education, 16, 649-659.

Soodak, L. C., \& Podell, D. M. (1996). Teacher efficacy: Toward the understanding of a multi-faceted construct. Teaching \& Teacher Education, 12, 401- 411.

Timmerman, G. (2009). Teacher educators modeling their teachers? European journal of teacher education, 32 (3), 225-238.

Tschannen-Moran, M., Woolfolk Hoy, A., \& Hoy, W. K. (1998). Teacher efficacy: Its meaning and measure. Review of Educational Research, 68(2), 202-248.

Tschennan-Moran, M., \& Woolfolk Hoy, A. (2001). Teacher efficacy: capturing an elusive construct. Teaching and Teacher Education, 17, 783-805.

Wheatley, K. F. (2005). The case for reconceptualizing teacher efficacy research. Teaching and Teacher Education $21,747-766$.

Woolfolk, A. E., Rosoff, B., \& Hoy, W. K. (1990). Teachers' sense of efficacy and beliefs about control. Journal of Educational Psychology, 82, 81-91. 
Woolfolk Hoy, A., \& Spero, R. B. (2005). Changes in teacher efficacy during the early years of teaching: A comparison of four measures. Teaching and Teacher Education, 21, 343-356.

Table 1. Total Variance Explained Extraction Method: Principal Axis Factoring

\begin{tabular}{|l|c|c|c|}
\hline Factors & \multicolumn{3}{|c|}{ Rotation Sums of Squared Loadings } \\
\hline & Eigenvalues & $\begin{array}{c}\text { \% of } \\
\text { Variance }\end{array}$ & Cumulative \% \\
\hline $\begin{array}{l}\text { 1. Efficacy for Playing } \\
\text { Critical and Social Roles }\end{array}$ & 3.659 & 11.434 & 11.434 \\
\hline $\begin{array}{l}\text { 2. Efficacy for } \\
\text { Instructional Strategies }\end{array}$ & 3.338 & 10.431 & 21.865 \\
\hline $\begin{array}{l}\text { 3. Efficacy for Classroom } \\
\text { management }\end{array}$ & 3.277 & 10.242 & 32.107 \\
\hline $\begin{array}{l}\text { 4. Efficacy for Student } \\
\text { Engagement }\end{array}$ & 2.402 & 7.505 & 39.612 \\
\hline
\end{tabular}

Table 2. Descriptive Statistics

\begin{tabular}{|c|c|c|c|c|}
\hline & Minimum & Maximum & Mean & $\begin{array}{c}\text { Std. } \\
\text { Deviation }\end{array}$ \\
\hline item1 & 1 & 9 & 6.63 & 1.764 \\
\hline item2 & 2 & 9 & 6.42 & 1.614 \\
\hline item3 & 2 & 9 & 7.46 & 1.541 \\
\hline item4 & 1 & 9 & 6.88 & 1.650 \\
\hline item5 & 3 & 9 & 7.37 & 1.519 \\
\hline item6 & 3 & 9 & 7.49 & 1.395 \\
\hline item7 & 3 & 9 & 7.25 & 1.482 \\
\hline item8 & 1 & 9 & 5.48 & 2.094 \\
\hline item9 & 1 & 9 & 7.02 & 1.555 \\
\hline item 11 & 3 & 9 & 7.21 & 1.466 \\
\hline item 12 & 2 & 9 & 7.50 & 1.587 \\
\hline item13 & 3 & 9 & 6.81 & 1.473 \\
\hline item14 & 1 & 9 & 6.62 & 1.661 \\
\hline item 15 & 1 & 9 & 6.01 & 2.190 \\
\hline item 16 & 2 & 9 & 7.15 & 1.655 \\
\hline item17 & 3 & 9 & 7.01 & 1.510 \\
\hline item 18 & 1 & 9 & 6.66 & 1.846 \\
\hline item19 & 1 & 9 & 6.20 & 2.025 \\
\hline item 20 & 4 & 9 & 7.79 & 1.271 \\
\hline item 21 & 3 & 9 & 7.07 & 1.446 \\
\hline item 22 & 1 & 9 & 6.14 & 2.129 \\
\hline item 23 & 3 & 9 & 7.06 & 1.614 \\
\hline item24 & 3 & 9 & 7.35 & 1.447 \\
\hline item 25 & 3 & 9 & 8.26 & 1.195 \\
\hline item 26 & 3 & 9 & 7.18 & 1.580 \\
\hline item 27 & 3 & 9 & 7.73 & 1.569 \\
\hline item 28 & 3 & 9 & 7.35 & 1.496 \\
\hline item29 & 2 & 9 & 7.17 & 1.618 \\
\hline item30 & 3 & 9 & 7.11 & 1.610 \\
\hline item31 & 1 & 9 & 6.48 & 1.981 \\
\hline item 32 & 3 & 9 & 7.37 & 1.436 \\
\hline item33 & 1 & 9 & 6.12 & 2.057 \\
\hline
\end{tabular}


Table 3. The Factor Structure of TSES-CP

\section{Factor 1: Efficacy for Playing Critical and Social Roles}

33. To what extent can you, as a teacher, act toward bringing about social changes?

8. How much might you change students into socio-politically responsible participants in society?

15. How much can you raise students' awareness of social, economic, etc. problems in society?

31. To what extent can you help students know themselves and their social status better?

2. How much can you do to help your students think critically? (Previously, i.e. in the original questionnaire, under Efficacy for Student Engagement)

22. How much can you assist families in helping their children do well in class work? (Previously under Efficacy for Student Engagement)

5. How much can you relate the materials to students' real life?

Factor 2: Efficacy for Instructional Strategies

19. To what extent can you help students produce their own learning materials? (added item)

18. How much can you use a variety of assessment strategies? (Previously under Efficacy for Instructional Strategies)

23. How well can you implement alternative strategies in your classroom? (Previously under Efficacy for Instructional Strategies)

7. How well can you respond to difficult questions from your students? (Previously under Efficacy for Instructional Strategies)

17. How much can you do to adjust your lessons to the proper level for individual students? (Previously under Efficacy for Instructional Strategies)

11. To what extent can you craft good questions for your students? (Previously under Efficacy for Instructional Strategies)

13. How much can you do to foster student creativity? (Previously under Efficacy for Student Engagement)

9. How much can you do to help your students value learning? (Previously under Efficacy for Student Engagement)

14. How much can you do to improve the understanding of a student who is failing? (Previously under Efficacy for Student Engagement)

\section{Factor 3: Efficacy for Classroom Management}

28. How much can you do to calm a student who is disruptive or noisy? (Previously under Efficacy for Classroom Management)

12. How much can you do to get students to follow classroom rules? (Previously under Efficacy for Classroom Management)

26. How well can you keep a few problem students from ruining an entire lesson? (Previously under Efficacy for Classroom Management)

30. How well can you establish routines to keep activities running smoothly? (Previously under Efficacy for Classroom Management)

3. How much can you do to control disruptive behavior in the classroom? (Previously under Efficacy for Classroom Management)

16. How well can you establish a classroom management system with each group of students? (Previously under Efficacy for Classroom Management)

32. To what extent can you make your expectations clear about student behavior?

(Previously under Efficacy for Classroom Management)

25. How much can you have friendly relationship with students? (added item)

1. How much can you cope with students difficult to please?(Previously under Efficacy for Classroom Management)

Factor 4: Efficacy for Student Engagement

6. How much can you do to get students to believe they can do well in their class work? ( Previously under Efficacy for Student Engagement)

27. How much can you learn from your own classes? (added item)

4. How much can you do to motivate students who show low interest in class work? (Previously under Efficacy for Student Engagement)

21. How well can you respond to defiant students? (Previously under Efficacy for Classroom Management)

29. To what degree can you invite students to contribute to the decisions made in the classroom? (added item)

24. How well can you provide appropriate challenges for very capable students? under Efficacy for Instructional Strategies) 
Table 4. Reliability Estimate

\begin{tabular}{|c|c|c|c|c|c|}
\hline & Total & Factor 1 & Factor 2 & Factor 3 & Factor 4 \\
\hline $\begin{array}{c}\text { Cronbach's } \\
\text { Alpha }\end{array}$ & .924 & .797 & .870 & .802 & 740 \\
\hline
\end{tabular}

\section{Appendix A}

\section{Teachers' Sense of Efficacy Scale-CP}

Male $\square$ Female $\square \quad$ Teaching experience: .... Years/months $\quad$ Name (optional):

Teacher beliefs

How much can you do?

\begin{tabular}{|c|c|c|c|c|c|c|c|c|c|}
\hline $\begin{array}{l}\text { Directions: This questionnaire is designed to help us } \\
\text { gain a better understanding of the kinds of things that } \\
\text { create difficulties for English teachers in their school } \\
\text { activities. Please indicate your opinion about each of the } \\
\text { statements below. Your answers are confidential. }\end{array}$ & $\begin{array}{c}\text { Nothing } \\
\text { (1) }\end{array}$ & (2) & $\begin{array}{l}\text { Very little } \\
\text { (3) }\end{array}$ & (4) & $\begin{array}{c}\text { Some } \\
\text { influence } \\
(5)\end{array}$ & (6) & $\begin{array}{c}\text { Quite } \\
\text { a bit } \\
(7)\end{array}$ & (8) & $\begin{array}{l}\text { A } \\
\text { great } \\
\text { deal } \\
(9)\end{array}$ \\
\hline $\begin{array}{l}\text { 1. How much can you cope with students difficult to } \\
\text { please? }\end{array}$ & & & & & & & & & \\
\hline $\begin{array}{l}\text { 2. How much can you do to help your students think } \\
\text { critically? }\end{array}$ & & & & & & & & & \\
\hline $\begin{array}{l}\text { 3. How much can you do to control disruptive behavior } \\
\text { in the classroom? }\end{array}$ & & & & & & & & & \\
\hline $\begin{array}{l}\text { 4. How much can you do to motivate students who } \\
\text { show low interest in class work? }\end{array}$ & & & & & & & & & \\
\hline $\begin{array}{l}\text { 5. How much can you relate the materials to students' } \\
\text { real life? }\end{array}$ & & & & & & & & & \\
\hline $\begin{array}{l}\text { 6. How much can you do to get students to believe } \\
\text { they can do well in their class work? }\end{array}$ & & & & & & & & & \\
\hline $\begin{array}{l}\text { 7. How well can you respond to difficult questions } \\
\text { from your students? }\end{array}$ & & & & & & & & & \\
\hline $\begin{array}{l}\text { 8. How much might you change students into } \\
\text { socio-politically responsible participants in society? }\end{array}$ & & & & & & & & & \\
\hline $\begin{array}{l}\text { 9. How much can you do to help your students value } \\
\text { learning? }\end{array}$ & & & & & & & & & \\
\hline $\begin{array}{l}\text { 10. How much can you gauge student comprehension } \\
\text { of what you have taught? }\end{array}$ & & & & & & & & & \\
\hline $\begin{array}{l}\text { 11. To what extent can you craft good questions for } \\
\text { your students? }\end{array}$ & & & & & & & & & \\
\hline $\begin{array}{l}\text { 12. How much can you do to get students to follow } \\
\text { classroom rules? }\end{array}$ & & & & & & & & & \\
\hline 13. How much can you do to foster student creativity? & & & & & & & & & \\
\hline $\begin{array}{l}\text { 14. How much can you do to improve the } \\
\text { understanding of a student who is failing? }\end{array}$ & & & & & & & & & \\
\hline $\begin{array}{l}\text { 15. How much can you raise students' awareness of } \\
\text { social, economic, etc. problems in society? }\end{array}$ & & & & & & & & & \\
\hline $\begin{array}{l}\text { 16. How well can you establish a classroom } \\
\text { management system with each group of students? }\end{array}$ & & & & & & & & & \\
\hline $\begin{array}{l}\text { 17. How much can you do to adjust your lessons to the } \\
\text { proper level for individual students? }\end{array}$ & & & & & & & & & \\
\hline $\begin{array}{l}\text { 18. How much can you use a variety of assessment } \\
\text { strategies? }\end{array}$ & & & & & & & & & \\
\hline $\begin{array}{l}\text { 19. To what extent can you help students produce their } \\
\text { own learning materials? }\end{array}$ & & & & & & & & & \\
\hline $\begin{array}{l}\text { 20. To what extent can you provide an alternative } \\
\text { explanation or example when students are confused? }\end{array}$ & & & & & & & & & \\
\hline 21. How well can you respond to defiant students? & & & & & & & & & \\
\hline $\begin{array}{l}\text { 22. How much can you assist families in helping their } \\
\text { children do well in class work? }\end{array}$ & & & & & & & & & \\
\hline
\end{tabular}




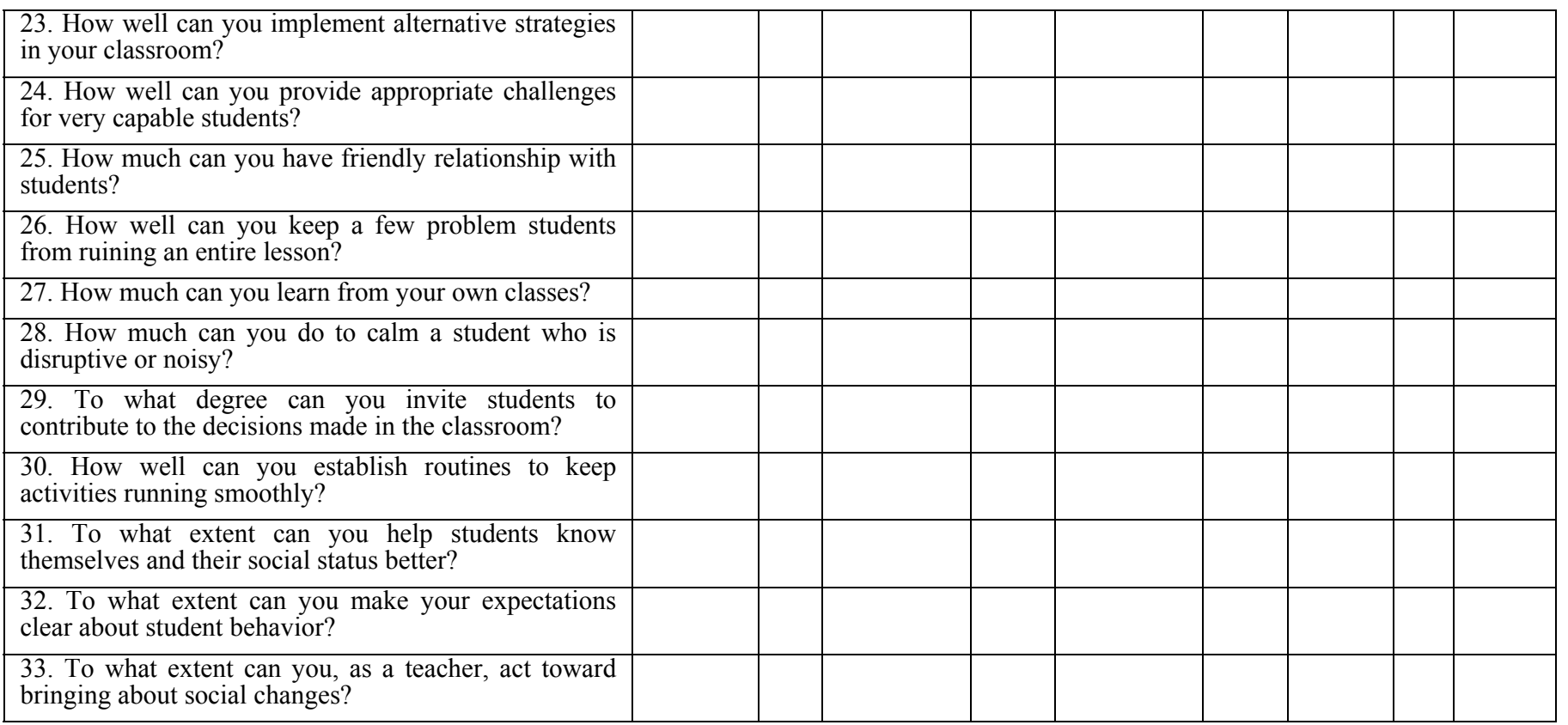

